\title{
MENANGGULANGI TINDAK PIDANA NARKOTIKA DIHUBUNGKAN DENGAN TUJUAN PEMIDANAAN
}

\author{
Basuki \\ Anggota Badan Narkotika Nasional \\ e-mail: basuki.mbspolri@yahoo.com
}

\begin{abstract}
Abstrak-Narkotika merupakan kejahatan luar biasa (extra ordinary crime) yang dilakukan secara rapi dan terorganisir. Untuk menanggulanginya negara menggunakan pidana mati. Namun demikian pidana mati yang selama ini diterapkan kepada bandar dan pengedar narkotika terus menimbulkan persoalan mengenai kontribusinya dalam mencapai tujuan pemidanaan terutama mengurangi angka tindak pidana narkotika secara nasional. Penelitian ini bertujuan untuk mengetahui penerapan sanksi pidana mati dalam memberikan kontribusi penanggulangan tindak pidana narkotika dihubungkan dengan tujuan pemidanaan dan penerapan sanksi pidana mati terhadap pelaku tindak pidana narkotika di masa yang akan datang untuk memberikan keadilan.
\end{abstract}

Kata Kunci: Tindak Pidana Narkotika, Tujuan Pemidanaan, Pidana Mati.

Abstract-Narcotics trafficking is an extraordinary crime pulled off in a neat and organized way. To overcome that crime, the country use the death penalty. However, the death penalty that has been applied to the druglords and narcotic dealers continue to conduce the question of the contribution towards achieving the purpose of the sentencing itself, especially in reducing the number of narcotic crime nationwide. This study purpose is to find out the application of death penalty in contributing to reduction of narcotic cases, linked to the purpose of sentencing and the application of the death penalty sanctions against the criminals in the future to achieve justice.

Keywords: Narcotics Act, Goal of Sentencing, Death Penalty.

\section{A. PENDAHULUAN}

Perdagangan narkotika yang

dijalankan di Indonesia oleh para bandar dan pengedar mampu memperoleh keuntungan yang sangat besar. Jika di Malaysia harga Shabu hanya setara dengan nilai Rp. 450 juta/kg, maka harga Shabu yang sama di Indonesia bisa mencapai $\operatorname{Rp~1,2~}$ milyar/kg. Menurut data Badan Narkotika Nasional (BNN) omzet perdagangan narkoba di Indonesia diperkirakan mencapai nilai $\mathrm{Rp} 20$ triliyun, itulah sebabnya Indonesia dikatakan sebagai surga bagi pengedar dan bandar narkotika internasional (Achmad Rifa'i, 2014:3).

Pada praktik peradilan hakim telah banyak menjatuhkan sanksi pidana mati, (Lili Rasjidi, 1999:265) khususnya terhadap pelaku kejahatan 
narkotika yang biasanya dilakukan secara terorganisir dan dengan jumlah narkotika yang sangat banyak, karena dipandang pelaku kejahatan narkotika ini membahayakan keselamatan masyarakat terutama generasi muda (Aminal Umam, 2011:54). Tujuan dijatuhkannya pidana mati dalam rangka memberikan efek jera (deterrence effect) pada pelaku kejahatan narkotika yang dilakukan secara terorganisir dan sistematis yang telah menyentuh semua kalangan masyarakat(Husni Syam, 2012 : 243). Mencermati aturan sanksi pidana mati dalam Undang- undang Nomor 35 Tahun 2009 Tentang Narkotika tergolong cukup berat dan tegas disebutkan dalam undang-undang dan telah banyak dijatuhkan hakim di tingkat pertama, banding, maupun kasasi. Akan tetapi fakta dilapangan menunjukan intensitas kejahatan narkotika masih cukup tinggi. Data pengungkapan kasus tindak pidana narkotika, psikotropika dan zat adiktif lainnya selama tahun 2012 sampai 2014 cenderung mengalami peningkatan. Hal itu dapat dilihat pada tabel di bawah ini:

Tabel 1.1

Data Pengungkapan Kasus Narkotika

Berdasarkan Penggolongan Narkotika Tahun 2012-2014

\begin{tabular}{|l|c|c|c|c|}
\hline \multirow{2}{*}{\multicolumn{1}{|c|}{ Kasus }} & \multicolumn{3}{|c|}{ Tahun } & \multirow{2}{*}{ Jumlah } \\
\cline { 2 - 4 } & $\mathbf{2 0 1 2}$ & $\mathbf{2 0 1 3}$ & $\mathbf{2 0 1 4}$ & $\mathbf{6 2 . 8 4 6}$ \\
\hline Narkotika & 18.977 & 21.119 & 22.750 & $\mathbf{4 . 1 7 9}$ \\
\hline Psikotropika & 1.729 & 1.612 & 838 & $\mathbf{3 1 . 4 7 7}$ \\
\hline $\begin{array}{l}\text { Bahan Adiktif } \\
\text { Lainnya }\end{array}$ & 7.917 & 12.705 & 10.855 & $\mathbf{9 8 . 5 0 2}$ \\
\hline Jumlah & $\mathbf{2 8 . 6 2 3}$ & $\mathbf{3 5 . 4 3 6}$ & $\mathbf{3 4 . 4 4 3}$ & \\
\hline
\end{tabular}

Sumber: Polri, Maret 2015.

Peningkatan prevalensi penyalahgunaan narkotika akan terus meningkat jika tidak ada upaya pencegahan. Diprediksi pada tahun 2016 prevalensi penyalahunaan narkoba akan meningkat $0,6 \%$ dibandingkan dengan tahun sebelumnya yaitu sebanyak 5,1 juta orang.

Sementara di pihak lain aparat penegak hukum terus melakukan penuntasan dalam menyelesaikan berbagai kasus narkotika yang pelakunya WNI maupun WNA. Data 
di bawah ini dapat menunjukan ditangani/diungkap secara nasional. prestasi penegak hukum dalam yaitu: menyelesaikan perkara yang telah

Tabel 1.2

Data Penyelesaian Kasus Narkotika

Berdasarkan Penggolongan Narkotika Tahun 2012-2014

\begin{tabular}{|l|c|c|c|c|}
\hline \multirow{2}{*}{ Kasus } & \multicolumn{3}{|c|}{ Tahun } & \multirow{2}{*}{ Jumlah } \\
\cline { 2 - 4 } & $\mathbf{2 0 1 2}$ & $\mathbf{2 0 1 3}$ & $\mathbf{2 0 1 4}$ & 41.571 \\
\hline Narkotika & 11.346 & 13.775 & 16.450 & $\mathbf{2 . 1 8 2}$ \\
\hline Psikotropika & 873 & 964 & 345 & $\mathbf{1 8 . 8 0 3}$ \\
\hline $\begin{array}{l}\text { Bahan Adiktif } \\
\text { Lainnya }\end{array}$ & 4.612 & 7.518 & 6.673 & $\mathbf{6 2 . 5 5 6}$ \\
\hline Jumlah & $\mathbf{1 6 . 8 3 1}$ & $\mathbf{2 2 . 2 5 7}$ & $\mathbf{2 3 . 4 6 8}$ & \\
\hline
\end{tabular}

\section{Sumber: Polri, Maret 2015.}

Berdasarkan data di atas menggambarkan bahwa intensitas perdagangan gelap narkotika cenderung mengalami peningkatan dan di setiap tahun terjadi tunggakan kasus narkotika, psikotropika dan zat adiktif lainnya, karena jumlah pengungkapan kasus dari tahun ke tahun relatif meningkat, sementara di sisi lain SDM yang ada di lembaga penegak hukum mengalami keterbatasan, sehingga belum mampu menyelesaikan seluruh kasus yang berhasil diungkap.

Selanjutnya Sistem Database Pemasyarakatan (SDP) per tanggal 28 April 2014, didapatkan keadaan dari 252 lapas dan 211 rutan di seluruh Indonesia penghuninya berjumlah 164.066 orang narapidana dan tahanan. Dari jumlah 164.066 orang narapidana dan tahanan di seluruh penjara di Indonesia, jumlah narapidana dan tahanan perkara narkotika mencapai 67.786 orang, dengan perincian 48.087 orang narapidana dan 19.699 orang tahanan. Artinya $41,43 \%$ dari seluruh narapidana dan tahanan di penjara yang tersebar di seluruh Indonesia berlatar belakang pelaku kejahatan narkotika (Arif, 2007:186).

Dalam berbagai kasus kejahatan narkotika yang berhasil diungkap oleh penegak hukum Kepolisian, Kejaksaan maupun Badan Narkotika Nasional dan dijatuhi sanksi pidana mati oleh pengadilan. Masing-masing terpidana telah mendapat vonis yang sudah berkekuatan hukum tetap. 
Setelah mendapatkan vonis dan upaya hukum yang mereka tempuh tidak berhasil, maka masing-masing dari mereka menjalani masa pidana untuk menunggu pelaksanaan eksekusi pidana mati yang menjadi kewenangan Kejagung. Ada yang telah dieksekusi dan ada yang sedang menunggu masa pelaksanaan pidana mati. Hal ini dapat dilihat pada tabel di bawah ini:

Tabel 1.3

Data Jumlah Terpidana Mati

Kasus Narkotika Tahun 2012-2014

\begin{tabular}{|c|c|c|c|c|}
\hline \multirow{2}{*}{ Kasus } & \multicolumn{3}{|c|}{ Tahun } & \multirow{2}{*}{ Jumlah } \\
\cline { 2 - 4 } & $\mathbf{2 0 1 2}$ & $\mathbf{2 0 1 3}$ & $\mathbf{2 0 1 4}$ & \\
\hline Jumlah & 4 & 5 & 1 & 10 \\
\hline Belum Dieksekusi & 2 & 5 & 1 & 10 \\
\hline Sudah Dieksekusi & - & 2 & - & 2 \\
\hline Sisa & 4 & 3 & 1 & 8 \\
\hline
\end{tabular}

Sumber: Kejagung RI, Maret 2015.

Data di atas menggambarkan keseriusan pemerintah dalam melaksanakan eksekusi pidana mati. Mengingat bahwa peredaran gelap narkotika memerlukan peran dari setiap orang yang terlibat dalam memperlancar perdagangan barang haram tersebut dan orang-orang yang terlibat dalam perdagangan narkotika tidak hanya dilakukan oleh warga negara Indonesia saja, melainkan juga ada peran berbagai warga negara asing.

Adanya peran warga negara asing dalam perdagangan gelap narkotika di Indonesia menjadi indikasi bahwa kejahatan ini telah dilakukan secara terorganisir dengan baik, melibatkan jaringan internasional dan menjadikan Indonesia sebagai salah satu pasar yang cukup potensial dalam peredaran gelap narkotika. Sehingga menjadi sesuatu yang wajar apabila pemerintah Indonesia dengan tegas menindak setiap orang yang terlibat dalam kejahatan narkotika tanpa memandang status kewarganegaraan salah satunya dengan menerapkan sanksi pidana mati.

Terpidana mati kasus narkotika bukan hanya warga negara Indonesia saja namun terdapat warga negara lain seperti Filipina, Prancis, Nigeria, dan negara lainnya yang tentunya diantara 
negara tersebut tidak semuanya menyetujui pidana mati. Pemerintah Indonesia mendapat banyak tekanan dari pihak asing terkait dengan rencana eksekusi sejumlah WNA terpidana mati kasus narkotika. Seperti tekanan yang diberikan Australia melalui Perdana Menteri Tony Abbott dan Menteri Luar Negeri Julie Bishop yang sedang mempertimbangkan menarik Dubes Australia untuk Indonesia karena ada 2 (dua) orang Warga Negaranya yang di eksekusi. Jumlah terpidana kasus narkotika yang divonis dengan pidana mati dapat dilihat pada tabel di bawah ini:

Tabel 1.4

Data Jumlah Terpidana Narkotika yang Telah Dieksekusi Narkotika Tahun 2013-2016

\begin{tabular}{|c|c|}
\hline Tahun & Jumlah \\
\hline 2013 & 2 \\
\hline 2014 & - \\
\hline 2015 & 14 \\
\hline 2016 & 1 \\
\hline
\end{tabular}

Sumber: Polri, Maret 2015.

Upaya pemerintah dalam menanggulangi kejahatan narkotika dengan menggunakan sanksi pidana mati memerlukan evaluasi apakah pelaksanaan sanksi pidana mati kepada beberapa pelaku kejahatan narkotika benar-benar telah memberikan kontribusi untuk menurunkan angka kejahatan narkotika di wilayah negara Republik Indonesia.

Pertanyaan ini menjadi masalah yang diperdebatkan di berbagai kalangan yang pro dan kontra terhadap eksistensi pidana mati dalam sistem hukum nasional Indonesia termasuk dalam Undang-undang Nomor 35 Tahun 2009 tentang Narkotika yang menjadi dasar hukum aparat penegak hukum untuk menjatuhkan pidana mati pada pelaku narkotika. Kalangan yang pro menghendaki agar pidana mati dalam Undang-undang Narkotika mesti dipertahankan sebagai suatu sarana hukum untuk menanggulangi kejahatan narkotika yang semakin meluas dan menyentuh berbagai lapisan masyarakat di Indonesia sehingga memerlukan sanksi hukum yang tegas dan keras. Sementara pihak yang kontra pidana mati dalam Undang-undang Narkotika sudah seharusnya dihapuskan karena bagaimanapun pelaku kejahatan narkotika memiliki hak asasi yang tidak dapat dikurangi dan dicabut sekalipun oleh negara salah satunya 
adalah hak hidup. Oleh karena itu, kelompok yang kontra menganggap penerapan pidana mati pada terpidana narkotika dianggap bertentangan dengan HAM.

Untuk memperoleh jawaban atas perdebatan tersebut, maka menurut hemat penulis perlu melakukan penelitian secara komperhensif sehingga dapat mengupas secara tuntas general deterrence dan special deterrence dari pelaksanaan pidana mati pada terpidana kasus narkotika untuk menemukan jawaban yang dapat menentukan posisi perlu atau tidaknya mempertahankan pidana mati terhadap kejahatan narkotika.

Berdasarkan uraian dari latar belakang diatas, maka dapat dirumuskan permasalahan dalam penelitian ini adalah apakah penerapan sanksi pidana mati telah memberikan kontribusi yang segnifikan dalam menanggulangi tindak pidana narkotika dihubungkan dengan tujuan pemidanaan dan bagaimana seyogyanya penerapan sanksi pidana mati yang berkeadilan terhadap pelaku tindak pidana narkotika di masa yang akan datang?
B. HASIL DAN PEMBAHASAN

1. Penerapan Pidana Mati Dalam Memberikan Kontribusi Dalam Menanggulangi Tindak

Pidana Narkotika

Dihubungkan

Dengan

\section{Tujuan Pemidanaan}

Apabila melihat data pengungkapan peredaran gelap narkotika yang ada dari tahun ke tahun memang terus mengalami peningkatan. Namun demikian, fakta tersebut tidak bisa secara serta merta menjadi dasar dan acuan mutlak untuk memberikan kesimpulan bahwa pidana mati tidak efektif untuk menanggulangi peredaran gelap narkotika di Indonesia. Mengingat apabila dikaji secara sosiologis dan kriminologis masalah kejahatan bukanlah semata-mata persoalan hukum melainkan juga menjadi permasalahan sosial (Darwin Bustar, 2015:42), maka berangkat dari statment tersebut cukup logis apabila dikatakan bahwa peningkatan kasus perdagangan gelap narkotika di Indonesia bukan karena sanksi pidana mati yang diterapkan selama ini tidak efektif, melainkan peningkatan 
tersebut dipengaruhi oleh berbagai faktor sosio-ekonomi yang melingkupi masyarakat Indonesia dewasa ini. Faktor sosio-ekonomi tersebut antara lain:

\section{a. Adanya Supply and Demand}

Upaya yang dapat ditempuh adalah dengan memutus supply and demand. Yang dimaksud dengan memutus supply/pemenuhan ketersediaan narkotika adalah melakukan pemberantasan dengan cara menangkap para produsen, bandar, pengedar (sindikat narkotika) maupun dengan cara menggagalkan usaha penyelundupan barang-barang terlarang yang akan masuk ke Indonesia. Sedangkan untuk memutus demand adalah memutus kebutuhan atas permintaan narkotika oleh para pecandu atau korban yang terkena bujuk rayu dari para pengedar maupun bandar.

Meskipun telah ada BNN yang khusus menangani peredaran narkotika namun sampai saat ini belum mampu memotong mata rantai antara supply and demand dalam kasus narkotika, ternyata produsen, bandar semakin dekat dengan para penyalahguna narkotika. Kemampuan
BNN dan Bareskrim Polri saat ini hanya mampu mengungkap kasusnya saja, sementara untuk pencegahan belum berhasil.

\section{b. Faktor Ekonomi}

Tingginya angka kemiskinan dan pengangguran menyebabkan meningkatnya peredaran dan penyalahgunaan narkotika di Indonesia. Secara nasional kondisi saat ini yang tergambarkan adalah meningkatnya peredaran dan penyalahgunaan narkotika disebabkan oleh tingginya angka kemiskinan dan pengangguran yang berbanding lurus dengan rendahnya tingkat pendidikan. Pengangguran dan kemiskinan yang tinggi membuat orang mudah tergiur untuk mendapatkan uang banyak dengan cara yang mudah tanpa memikirkan halal-haramnya. Salah satunya dengan menjadi pengedar narkotika yang memperoleh imbalan cukup besar. Tapi semakin tinggi tingkat ekonomi seseorang juga membuatnya semakin mudah untuk mendapatkan narkotika. Oleh karena itu, strategi yang dijalankan oleh BNN secara nasional adalah dengan mendorong seluruh lapisan masyarakat untuk ikut berperan dalam 
Basuki, Menanggulangi Tindak Pidana Narkotika Dihubungkan Dengan Tujuan...

Pencegahan dan Pemberatasan Penyalahgunaan Perdagangan Gelap Narkotika (P4GN) sehingga dengan sendirinya masyarakat menjadi kebal terhadap narkotika.

Upaya pemberantasan narkotika semakin sulit dan memerlukan peran semua pihak terutama pemerintah untuk mengatasi persoalan kemiskinan yang terus melanda Indonesia. Kesulitan memberantas perdagangan gelap narkotika ini dikarenakan jaringan sindikat narkotika seperti siluman, tidak jarang jaringan narkotika menggunakan sel putus, artinya diantara pengedar narkotika itu sendiri tidak saling mengenal. Belum tentu pelaku yang tertangkap akan mengenal bandarnya secara langsung, kecuali jika ditelusuri secara cermat, mungkin saja akan diketahui bandar besar di balik peredaran narkotika tersebut (Hadiman, 1999:25).

Terlepas dari persoalan tersebut masalah kemiskinan dan pengangguran akan terus menjadi faktor korelatif kriminogen yang mempengaruhi peningkatan perdagangan gelap narkotika di Indonesia. Semakin tinggi angka pengangguran dan kemiskinan di perkotaan maupun pedesaan maka semakin tinggi pula potensi peningkatan perdagangan narkotika. Oleh karena itu, kebijakan di bidang pertumbuhan ekonomi menjadi salah satu kebijakan yang patut diprioritaskan untuk mendukung upaya penegakan hukum dalam menanggulangi dan meminimalisir perdagangan gelap narkotika.

Kebijakan di bidang kesejahteraan masyarakat merupakan salah satu langkah pendukung yang efektif dan efisien untuk menghindarkan masyarakat dalam jaringan peredaran narkotika yang terus menyasar generasi muda bangsa (Hariono, 2013:14). Selain itu juga perlu diimbangi dengan pemahaman akan bahaya narkotika terhadap kesehatan.

\section{c. Faktor Integritas Aparat Penegak Hukum}

Faktor lain yang mempengaruhi perdagangan gelap narkotika di Indonesia disebabkan karena banyaknya aparatur penegak hukum yang ikut terlibat dan bermain dalam peredaran narkotika. Mereka mengambil keuntungan pribadi dalam 
Basuki, Menanggulangi Tindak Pidana Narkotika Dihubungkan Dengan Tujuan...

penanganan kasus-kasus narkotika. untuk mendapatkan keuntungan Tidak jarang setiap kasus narkotika pribadi. selalu ada oknum aparat yang terlibat dalam jaringan peredaran narkotika (Mardani, 2007:18).

Peristiwa yang paling hangat adalah pada pertengahan 2016 bandar narkotika Fredy Budiman memberikan pengakuan bahwa dalam menjalankan bisnis haramnya Fredy dibantu dan didukung oleh para petinggi TNI/Polri. Bahkan dari mereka ada memesan harga narkotika yang diimpor dari Tiongkok untuk diperdagangkan di Indonesia. Pengakuan Fredy baru terkuak dengan adanaya testimoni yang disampaikan oleh Haris Azhar selaku koordinator kontras yang tidak setuju dengan penerapan pidana mati bagi terpidana narkotika.

Selama masih ada oknumoknum aparat penegak hukum yang bekerjasama dengan bandar narkotika di Indonesia, maka pemberantasan perdagangan gelap narkotika tidak akan pernah selesai, karena pihak yang semestinya menjadi kepanjangan tangan pemerintah untuk menghilangkan narkotika malah bekerjasama dengan bandar narkotika 
Skema 1.1

Kendala Penerapan Pidana Mati

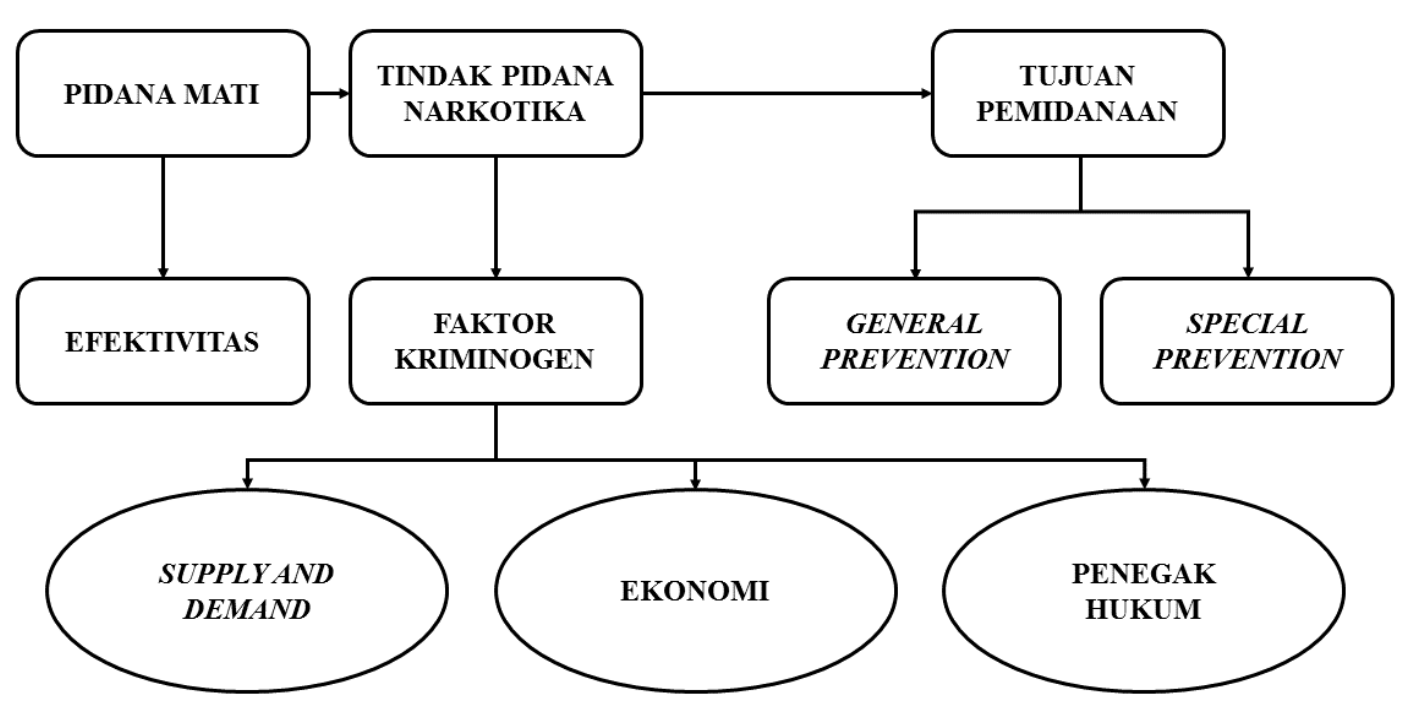

Ketiga faktor di atas menjadi penyebab atau pemicu tingginya perdagangan gelap narkotika di Indonesia. Oleh karena itu, meskipun pengadilan telah menjatuhkan pidana mati kepada para bandar dan pengedar narkotika tetapi belum memberikan kontribusi yang segnifikan dalam menanggulangi tindak pidana narkotika, sehingga tujuan pemidanaan yang dicitacitakan melalui pidana mati belum terealisasi.

Tujuan pemidanaan bisa dilihat teori-teori pemidanaan yang masih berlaku sampai sekarang ini antara lain: a. Teori pembalasan (retributuf theory) idenya adalah untuk membalas perbuatan tercela yang dilakukan oleh pelaku.

b. Teori relatif, esensi teori ini adalah untuk memberikan pencegahan agar masyarakat yang lain tidak melakukan perbuatan yang sama.

c. Teori gabungan (integratif theory) yang menggabungkan ide untuk memberikan pembalasan dan perbaikan atau pendidikan pada pelaku agar menyadari kesalahannya

(Lamintang, 1989:32).

Apabila melihat praktek pemidanaan yang dijalankan di Indonesia selama ini, maka dapat dikatakan bahwa Indonesia menganut 
teori integratif dengan menempatkan seorang pelaku kejahatan ke dalam Lembaga Pemasyarakatan sebagai wujud pidana/pembalasan juga bertujuan untuk mendidik dan membina agar pelaku menyadari kesalahannya dan menjadi orang baik kembali yang diterima di tengahtengah masyarakat.

Pendapat yang kontra terhadap penerapan pidana untuk terpidana narkotika mendasarkan pandangan mereka pada realitas dunia internasional, di mana saat ini trend masyarakat internasional adalah menghapuskan pidana mati. Pada tahun 2015 sekitar 102 negara telah menghapuskan pidana mati, 8 negara menghapuskan pidana mati terhadap kejahatan khusus, dan 34 negara tidak melakukan eksekusi atau moratorium (Nelvitia Purba, 2015:72).

Apabila dianalisis lebih jauh penulis melihat bahwa negara-negara yang menghapuskan pidana mati secara total untuk semua kategori tindak pidana merupakan negaranegara barat yang sudah maju dan mapan dari segi politik dan ekonomi. Salah satu contohnya adalah Swiss, Belanda Venezuela, Inggris dan
Irlandia Utara adalah sekian banyak dari negara maju yang menghapus pidana mati untuk semua tindak pidana termasuk narkotika. Di negara-negara tersebut tingkat catatan kriminal warganya cukup sedikit. Kondisi ini menunjukan bahwa masyarakat yang ada di negara penghapus pidana mati sudah memiliki ketaatan hukum yang tinggi ditambah dengan tingkat kemiskinan dan pengangguran yang rendah. Itu sebabnya pemerintah negara-negara tersebut berani mengambil keputusan untuk menghapuskan pidana mati secara total untuk semua kategori kejahatan karena situasi politik, ekonomi dan budayanya memungkinkan mengabolisionis pidana mati.

Kondisi negara yang menghapus pidana mati bila dibandingkan dengan Indonesia sangat jauh berbeda, secara politik Indonesia belum sepenuhnya mapan karena masih banyak isu-isu yang menyinggung suku, ras dan agama dalam demokrasi Indonesia. Sedangkan dari segi ekonomi masyarakat Indonesia masih banyak yang hidup di bawah garis 
kemiskinan dan tingkat pengangguran cukup tinggi yang tersebar di perkotaan maupun pedesaan. Situasi demikian menjadi pemicu para generasi muda bangsa untuk terlibat dalam jaringan narkotika. Mereka inilah yang rentan untuk bergabung dengan para sindikat narkotika regional, nasional dan internasional yang menjadi penyebab peningkatan kasus-kasus peredaran dan perdagangan gelap narkotika di Indonesia.

\section{Penerapan Sanksi Pidana} Mati yang Berkeadilan Terhadap Pelaku Tindak Pidana Narkotika di Masa yang Akan Datang

Menurut penulis penerapan pidana mati yang selama ini dilaksanakan oleh pemerintah kepada para pelaku tindak pidana narkotika masih cukup relevan untuk dipertahankan dalam sistem hukum pidana nasional Indonesia. Karena secara konstitusional dalam UUD 1945 pidana mati jelas tidak bertentangan dengan HAM terutama hak untuk hidup. Apabila pidana mati dihapuskan maka dikhawatirkan akan menimbulkan peningkatan perdagangan narkotika yang lebih besar dan dilaksanakan secara masif. Bangsa Indonesia dapat membayangkan narkotika sebagai kejahatan serius (the most serius crime) sudah diancam pidana mati saja angka pengungkapannya setiap tahun terus meningkat, apalagi bila pidana mati dihapuskan akan menambah dan mengundang para bandar besar untuk mendirikan bisnis narkotika secara besar-besaran di Indonesia, karena ancaman sanksinya rendah dan cenderung tidak memberikan efek jera.

Penulis berpandangan bahwa penerapan sanksi pidana mati terhadap pelaku tindak pidana narkotika seyogyanya tetap dipertahankan sebagai pidana khusus namun perlu diancamkan secara alternatif. Merujuk pada Konsep KUHP sebagai hukum yang dicitacitakan (ius constituendum) hukum pidana Indonesia, ketentuan yang mengatur mengenai pidana mati telah diatur secara selektif dan limitatif (Barda Nawawi, 2008:173).

Konsep KUHP tahun 2015 telah merumuskan jenis-jenis sanksi pidana 
Basuki, Menanggulangi Tindak Pidana Narkotika Dihubungkan Dengan Tujuan...

(strafsoort) dalam Pasal 66, 67 dan

68. Ketentuan mengenai jenis pidana diatur dalam Pasal 66 yang menyebutkan sebagai berikut:

1) Pidana Pokok terdiri atas:
a. Pidana penjara;
b. Pidana tutupan;
c. Pidana pengawasan;
d. Pidana denda; dan
e. Pidana kerja social.

2) Urutan pidana sebagaimana dimaksud pada ayat menentukan berat ringannya pidana.

Ketentuan mengenai pidana mati diatur dalam Pasal 67 Konsep KUHP yang menegaskan bahwa:

"Pidana mati merupakan pidana pokok yang bersifat khusus dan selalu diancamkan secara alternatif".

Selanjutnya ketentuan mengenai pidana tambahan diatur dalam Pasal 68 Konsep KUHP yang menyebutkan bahwa:

1) Pidana tambahan terdiri atas:

a. Pencabutan hak-hak tertentu;

b. Perampasan barang tertentu;

c. Pengumuman putusan hakim;

d. Pembayaran ganti kerugian;

e. Pemenuhan kewajiban adat setempat atau kewajiban menurut hukum yang hidup dalam masyarakat.

2) Pidana tambahan dapat dijatuhkan bersama-sama dengan pidana pokok, sebagai pidana yang berdiri sendiri atau dapat dijatuhkan bersama-sama dengan pidana tambahan yang lain.

3) Pidana tambahan berupa pemenuhan kewajiban adat setempat atau kewajiban menurut hukum yang hidup dalam masyarakat atau pencabutan hak yang diperoleh korporasi dapat dijatuhkan walaupun tidak tercantum dalam perumusan tindak pidana.

4) Pidana tambahan untuk percobaan dan pembantuan adalah sama dengan pidana tambahan untuk tindak pidananya.

Ketentuan yang mengatur secara khusus mengenai pelaksanaan pidana mati diatur dalam Pasal 91 Konsep KUHP yang mengatur bahwa:

1) Pelaksanaan pidana mati dapat ditunda dengan masa percobaan selama 10 (sepuluh) tahun, jika:
a. Reaksi masyarakat terhadap terpidana tidak terlalu besar;
b. Terpidana menunjukan rasa menyesal dan ada harapan untuk diperbaiki;
c. Kedudukan terpidana dalam penyertaan tidak terlalu penting; dan
d. Ada alasan yang meringankan.

2) Jika terpidana selama masa percobaan sebagaimana dimaksud pada ayat (1) menunjukan sikap dan perbuatan yang terpuji maka pidana mati dapat diubah menjadi pidana seumur hidup atau pidana penjara paling lama 20 (dua puluh) tahun dengan keputusan menteri yang menyelenggarakan urusan 
pemerintahan di bidang hukum dan hak asasi manusia.

3) Jika terpidana selama masa percobaan sebagaimana dimaksud pada ayat (1) tidak menunjukan sikap dan perbuatan yang terpuji serta tidak ada harapan untuk diperbaiki maka pidana mati dapat dilaksanakan atas perintah Jaksa Agung.

Berdasarkan rumusan di atas, dapat dikatakan bahwa pemerintah melalui kebijakan formulasi Konsep KUHP mendatang menggunakan asas keseimbangan dalam menerapkan sanksi pidana mati untuk menanggulangi kejahatan-kejahatan berat termasuk tindak pidana narkotika. Asas ini merupakan asas yang menggabungkan dua kepentingan secara bersamaan dalam proses pemidanaan yaitu kepentingan umum (masyarakat) dengan kepentingan khusus (individu/pelaku)

Asas keseimbangan ini menjadi spirit of Norm Pasal 91 Konsep KUHP yang mengedepankan kepentingan umum (masyarakat), juga memperhatikan kepentingan individu (pelaku) dalam menerapkan pidana mati. Melalui asas keseimbangan Konsep KUHP memberikan ramburambu bahwa penerapan pidana mati haruslah bersifat selektif, hati-hati dan berorientasi juga pada perlindungan/kepentingan individu. Oleh karena itu, Konsep KUHP memberikan ketentuan adanya "penundaan pelaksanaan pidana mati" atau "pidana mati bersyarat" dengan masa percobaan selama 10 (sepuluh) tahun.

Konsep KUHP ini mengakomodasi keinginan-keinginan dari kalangan yang pro dan kontra mengenai perlu atau tidaknya pidana mati dalam hukum pidana Indonesia. Kalangan yang pro lebih menitikberatkan pada kepentingan umum (masyarakat), sedangkan kelompok kontra mengutamakan kepentingan individu (hak hidup pelaku).

Konsep KUHP menerapkan pidana mati bersyarat karena adanya masa percobaan selama 10 tahun. Artinya terpidana narkotika diberikan kesempatan selama waktu tersebut untuk menyadari kesalahannya dan berperilaku baik, sehingga memungkinkan pidana mati yang sudah dijatuhkan kepadanya dapat diubah dengan pidana penjara seumur 
hidup atau 20 (dua puluh) tahun dicitacitakan dapat dijelaskan melalui penjara (Ahmad Rafiq, 2000:27). bagan di bawah ini:

Pidana mati dalam konsep KUHP sebagai hukum yang

Skema 1.2

Pidana Mati Dalam Konsep KUHP

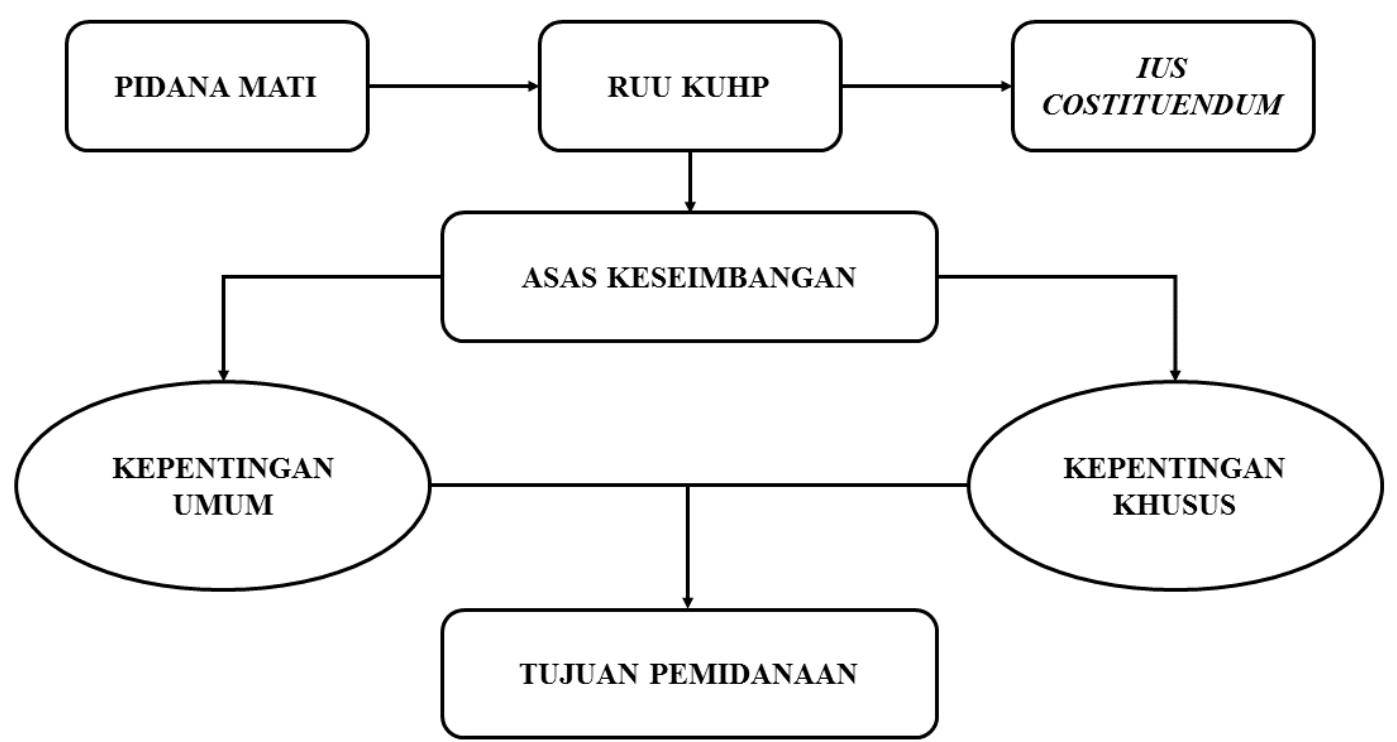

Bagan di atas menjelaskan bahwa pidana mati dalam Konsep KUHP menjadi sarana penal yang dapat diterapkan untuk menanggulangi tindak pidana narkotika di masa mendatang dan memberikan keadilan dengan menggabungkan dua kepentingan secara bersamaan dalam mencapai tujuan pemidanaan. Dengan rumusan sebagaimana tercantum dalam Pasal 91 Konsep KUHP, tujuan pemidanaan sebagai sarana resosialisasi pelaku dapat dilaksanakan sekalipun terpidana sudah dijatuhi pidana mati, sehingga terjadi keseimbangan antara kepentingan masyarakat dan pelaku tindak pidana narkotika. Tinggal menunggu kemauan pelaku untuk memperbaiki diri dan bertaubat untuk kembali menjadi masyarakat yang baik taat hukum.

Penulis mengkritisi ketentuan Pasal 91 ayat (2) dan (3) Konsep 
KUHP mengenai adanya perubahan sikap terpidana. Perumus RUU KUHP harus memasukan indikatorindikator apa saja yang dapat dijadikan ukuran bahwa terpidana telah menunjukan perubahan sikap menjadi lebih baik. Kalimat "menunjukan sikap dan perbuatan yang terpuji" ini memerlukan indikator yang jelas agar tidak menimbulkan perdebatan pada saat pelaksanan. Begitu pula sebaliknya dalam ayat (3) kalimat "tidak menunjukan sikap dan perbuatan yang terpuji serta tidak ada harapan untuk diperbaiki" perlu diberikan ukuran yang jelas agar ketentuan tersebut dapat dilaksanakan secara jelas.

Apabila dianalisis rumusan pidana mati yang tertuang dalam Konsep KUHP sudah sesuai dengan prinsip-prinsip yang termuat dalam putusan MK Nomor 2/PUU-V/2007 dan Nomor 3/PUU-V/2007 terkait pengujian Undangundang Narkotika. Prinsip-prinsip yang terkandung dalam putusan MK yang dimaksud yaitu pidana mati hanya dijatuhkan terhadap produsen dan bandar/pengedar narkotika. Pidana mati bukan lagi sebagai pidana pokok melainkan pidana yang bersifat khusus yang selalu diancamkan secara alternatif.

\section{SIMPULAN}

1. Penerapan pidana mati selama ini belum memberikan kontribusi yang segnifikan dalam menanggulangi tindak pidana narkotika. Fakta persidangan menunjukan bahwa telah banyak vonis mati yang dijatuhkan oleh hakim kepada pelaku tindak pidana narkotika sebagai produsen, bandar dan pengedar. Namun bila melihat trend tindak pidana narkotika masih cenderung mengalami peningkatan. Akan tetapi, pidana mati tidak serta merta dapat dikatakan tidak efektif, karena kontribusi pidana mati untuk mencapai tujuan pemidanaan secara integratif dipengaruhi oleh faktor sosioekonomi antara lain:
a. Supply and demand narkotika;
b. Tingginya angka kemiskinan dan pengangguran; 
Basuki, Menanggulangi Tindak Pidana Narkotika Dihubungkan Dengan Tujuan...

c. Adanya penegak hukum yang terlibat dalam perdagangan gelap narkotika.

Ketiga unsur di atas menjadi faktor korelatif kriminogen yang menyebabkan pidana mati belum mampu mencapai tujuan pemidanaan, sehingga angka kriminalitas narkotika cenderung meningkat. Oleh karena itu, penerapan pidana mati perlu didukung oleh kebijakan non-penal dalam mengatasi persoalan sosioekonomi yang selama ini mempengaruhi dan menghambat efektivitas penerapan pidana mati untuk mencapai tujuan pemidanaan.

2. Pidana mati masih relevan untuk dipertahankan di masa yang akan datang sebagai sarana penal dalam menanggulangi tindak pidana narkotika. Akan tetapi, penerapannya di masa mendatang harus dilaksanakan secara selektif dan hati-hati. Sebagaimana telah dirumuskan dalam RUU KUHP, pidana mati tidak perlu diterapkan secara mutlak melainkan diancamkan secara alternatif. Artinya terpidana diberikan kesempatan kurun waktu 10 (sepuluh) tahun untuk memperbaiki diri dan menyadari kesalahannya agar dapat mengubah ancaman pidana mati menjadi seumur hidup atau 20 (dua puluh) tahun penjara. Dengan demikian pidana mati dipandang lebih berkeadilan bagi pelaku tindak pidana narkotika karena adanya keseimbangan antara kepentingan masyarakat dengan kepentingan individu yang harus dilindungi.

\section{SARAN}

1. Perdagangan gelap narkotika sebagai suatu kejahatan yang terorganisir dan bersifat transnasional (transnational crime) dengan berbagai modus operandi yang selalu berubahubah memerlukan penanganan khusus dengan melakukan langkah-langkah strategis antara lain:

a. Bagi penegak hukum (Kepolisian dan 
Basuki, Menanggulangi Tindak Pidana Narkotika Dihubungkan Dengan Tujuan...

BNN/BNP/BNK, Kejaksaan dan Pengadilan) disarankan tetap melakukan penerapan sanksi pidana mati untuk produsen, bandar, dan pengedar sebagai upaya represif dalam memberikan efek jera sekaligus sebagai upaya memberikan kontribusi dalam mencapai tujuan pemidanaan untuk melindungi kepentingan umum (masyarakat).

b. Penegak hukum sebaiknya bekerjasama dengan pihakpihak terkait untuk melakukan kegiatan pencegahan berupa sosialisasi kepada masyarakat terutama di tempat yang rawan penyelundupan narkotika seperti pelabuhan dan bandara untuk memutus rantai suplay and demand jaringan narkotika illegal, memberikan informasi kepada masyarakat akan bahaya narkotika terhadap kesehatan melalui media massa (prevention without punishment).

c. Bagi pemerintah disarankan agar terus mengeluarkan berbagai kebijakan yang berorientasi pada pengentasan kemiskinan dan pengangguran sebagai langkah pencegahan untuk menutup perekrutan kurir atau pengedar narkotika dari kelompok masyarakat tidak mampu. Diperkuat dengan langkah reformasi birokrasi dan pembinaan terhadap personel agar tidak terlibat dalam peredaran narkotika. Mengingat integritas penegak hukum merupakan kunci terpenting guna menentukan keberhasilan pemberantasan tindak pidana narkotika.

2. Pelaksanaan pidana mati untuk masa yang akan datang sebaiknya mengutamakan kepentingan umum (masyarakat) dan kepentingan individu (pelaku) yang didasarkan pada asas keseimbangan sebagaimana 
Basuki, Menanggulangi Tindak Pidana Narkotika Dihubungkan Dengan Tujuan...

dirumuskan dalam RUU KUHP sebagai ius constituendum untuk menciptakan keseimbangan antara keduanya yang memberikan kesempatan agar terpidana dapat menghindari pidana mati, sepanjang menunjukan perubahan sikap yang lebih baik.

\section{DAFTAR PUSTAKA}

Achmad Ali, Menguak Realitas Hukum, Artikel Dalam Bidang Hukum, Prenada Media Group, 2001.

Achmad Rifa'i, Narkoba di Balik Tembok Penjara, Aswaja Pressindo, Yogyakarta, 2014.

Ahmad Rafiq, Mempersoalkan Pidana Mati, CV Firma, Medan, 2000.

Aminal Umam, Ketidakadilan dalam Penanganan Kejahatan Narkoba, Majalah Hukum Varia Peradilan, Edisi Nomor 33 Februari, Ikahi Jakarta, 2011.

Badan Narkotika Nasional, Advokasi Pencegahan Penyalahgunaan Narkoba, Jakarta, 2007.

Barda Nawawi Arief, RUU KUHP Baru Sebuah Rekonstruksi Sistem Hukum Pidana
Indonesia, Badan Penerbit Undip, Semarang, 2008.

Darwin Bustar, dkk, Pencegahan dan Pemberantasan

Penyalahgunaan Peredaran Gelap Narkotika (P4GN), Jakarta, 2015.

Hadiman, Menguak Misteri Maraknya Narkoba di Indonesia, Badan Kerjasama Sosial Usaha Pembinaan Warga Tama, Jakarta, 1999.

Hariyono dkk, Membangun Negara Hukum Bermartabat, Setara Press, Malang, 2013.

Husni Syam, Tindak Pidana Narkotika Sebagai Kejahatan Internasional, dalam Hukum untuk Manusia, Pilar Utama, Mandiri bekerjasama dengan Unisba, Bnadung, 2012.

Lamintang, Hukum Penitensier Indonesia, Armico, Bandung, 1984.

Lili Rasjidi, Pidana Mati dalam Tinjauan Filsafat, Alumni, Bandung, 1999.

Mardani, Penyalahgunaan Narkoba, Rajawali Pers, Jakarta, 2007.

Nelvitia Purba dan Sri Sulistyawati, Pelaksanaan Pidana Mati, Graha Ilmu, Yogyakarta, 2015. 